\title{
Investigation on the Effect of Garment Fit on Thermal Transfer Performance of Clothing by Combining Non-Contact Measuring Tools
}

\author{
Temassız Ölçüm Cihazları Kullanılarak Giysi Bedenlerinin Giysi Termal Transfer \\ Performansına Etkisinin İncelenmesi
}

\author{
Sertaç GÜNEY $^{1} \mathbb{D}$, Hilal BALCI ${ }^{2} \mathbb{D}$, İbrahim ÜÇGÜL ${ }^{1}$ \\ ${ }^{1}$ Süleyman Demirel Üniversitesi, Mühendislik Fakültesi, Tekstil Mühendisliği Bölümü, 32260, ISPARTA \\ ${ }^{2}$ İstanbul Arel Üniversitesi, Meslek Yüksekokulu, Moda Tasarımı Programı, 34295, ISTANBUL
}

\begin{abstract}
Next-to-skin sportswear are generally produced from knitted strecth fabrics, which get extended on wearing and remain in the extended state. Since they are worn next to skin and are direct contact with the body surface, their thermal comfort properties are effective on overall clothing comfort. In this paper, an investigation has been made to evaluate the effect of garment fit and fabric extension on the thermal transfer performance of clothing. The method using the combination of infrared thermal camera and 3D virtual garment simulation has been developed considering the fabric extension and clothing surface temperature of different body parts. Two type T-shirts were produced by changing the bust and waist measurements and their thermal transfer performance were investigated in wear trials on subjects having different size. Fabric extension results were taken from virtual avatar in 3D simulation having the same body measurements as subjects. Temperatures changes on different body parts according to the wearing protocol were investigated in thermal camera software (Flir Tools). The experimental results show that compression garment fit and fabric extension influence the heat transfer and clothing surface temperatures. In the sportswear industry, Optimal garment fit should be defined for designing sportswear, especially for performance sportswear.
\end{abstract}

Keywords: Next-to-skin sportswear, garment fit, thermal comfort, 3D virtual simulation

$\ddot{\mathbf{O} z}$

Vücuda tam oturan spor kıyafetleri genellikle, örme kumaşlardan üretilir ve giyildiğinde uzar ve uzamış halde vücut yüzeyinde kalırlar. Vücut yüzeyiyle doğrudan temas ettikleri için termal konfor özellikleri genel giysi konforunda etkilidir. Bu çalışmada, vücuda oturma durumunun ve kumaş uzamasının, giysinin termal transfer performansı üzerindeki etkileri araştırılmıştır. Kızılötesi termal kamera ve üçboyutlu sanal giysi simülasyonunun birleşimini kullanan bu yöntem, farklı vücut bölgeleri üzerindeki kumaş uzamaları ve giysi yüzey sıcaklıkları dikkate alınarak geliştirilmiştir. Gögüs ve bel ölçümleri değiştirilerek iki tip tişört üretilmiş ve farklı beden ölçülerindeki katılımcılarla giyim denemeleriyle 1sı transfer performansları incelenmiştir. Kumaş uzama değerleri, katılımcılarla aynı vücut ölçülerine sahip olan üçboyutlu simülasyondaki sanal mankenler üzerinden elde edilmiştir. Termal kamera yazılımıyla (Flir Tools) giyim denemesi protokolüne göre farklı vücut bölgelerindeki sıcaklık değişiklikleri incelenmiştir. Deneysel sonuçlar, giysinin vücuda oturma durumunun ve kumaş uzamasının, ısı transferini ve giysi yüzey sıcaklıklarını etkilediğini göstermektedir. Spor giyim endüstrisinde, özellikle performans spor kıyafetlerinin tasarımında en uygun vücuda oturma oranı tanımlanmalıdır.

Anahtar Kelimeler: Vücuda oturan spor giysiler, vücuda oturma durumu, termal konfor, Üç boyutlu Sanal Simülasyon

\section{I.INTRODUCTION}

Compression sportswear has become attractive in personel or team sports in recent years. A pleasing contact perception, reasonable pressure profile and optimum thermal-moisture properties are fundamental to promote comfort and physical 
performance and health to the athletes since these garments are typically designed to directly maintain contact with athlete's body [1]. Compression garments elongates up to $10 \%$ in lenght and $60 \%$ in width when worn, depending on the variations in body circumference. This stretch also changes the loop shape, density and thickness of fabric. All these changes are expected to affect significantly the comfort behaviour of fabrics [2]. Heat and mass transfer through the garment is not only dependent on these properties of the fabrics used in the garment but also on the change in the contact area and the air gap thickness between the garment layers and outer adjacent air layer. The thickness of air layers and the magnitude of contact area can be affected by the mechanical properties of the fabric and the garment properties (various ease allowances due to the different fits and styles), moisture content, body posture and the movement of the body [3]. Compression sportswear are worn next to skin and are direct contact with the body surface and minimize the air gap thickness so that the fabric thermal comfort properties are effective on overall clothing comfort. Sport garments are at the interface between the human body and the environment and therefore modify the heat and mass transfers occurring at the skin surface. Clothing interacts with physiological and physical processes impacting skin temperature that can be assessed by infrared thermography. The assessment of sport garments, specifically their impact on the skin using this technique, enables great advances in the field of garment design and its consequence on sport performance and thermal comfort, both for recreational and professional athletes [4]. In this study, we determined the fabric extension on different body parts and related this with the clothing surface temperatures using the combination of infrared thermal camera and 3D virtual garment simulation.

\section{II.EXPERIMENTAL SET-UP AND PROCEDURE}

\subsection{Materials}

Two type of tshirts were produced from the same strecth knitted fabric made of $86 \%$ Polyester and 14\% Elastane. The fabric properties were given in Table 1.

Table 1. Fabric properties

\begin{tabular}{|l|l|l|l|l|l|}
\hline $\begin{array}{l}\text { Fibre Compo- } \\
\text { sition }\end{array}$ & $\begin{array}{l}\text { Fabric } \\
\text { Structure }\end{array}$ & $\begin{array}{l}\text { Fabric } \\
\text { Mass } \\
\left(\mathrm{g} / \mathrm{m}^{2}\right)\end{array}$ & $\begin{array}{l}\text { Fabric } \\
\text { Thickness } \\
(\mathrm{mm})\end{array}$ & $\begin{array}{l}\text { Air Per- } \\
\text { meability } \\
\left(\mathrm{l} / \mathrm{m}^{2} / \mathrm{s}\right)\end{array}$ & $\begin{array}{l}\text { Thermal } \\
\text { Resistance } \\
\left(\mathrm{m}^{2} \mathrm{~K} / \mathrm{W}\right)\end{array}$ \\
\hline $\begin{array}{l}86 \% \text { PES 14\% } \\
\text { Elastane }\end{array}$ & $\begin{array}{l}\text { weft knit- } \\
\text { ted }\end{array}$ & 315 & 0.49 & 62.2 & 7.4 \\
\hline
\end{tabular}

All the tshirts had the same style of sleeveless but the size gradually decreased at bust and waist girths. The measurements of tshirts are shown in Table 2.

Table 2. Measurements of experimental tshirts (cm)

\begin{tabular}{|l|l|l|}
\hline Tshirt Code & Bust & Waist \\
\hline G1 & 40 & 38 \\
\hline G2 & 38 & 36 \\
\hline
\end{tabular}

\subsection{Methods}

Three men having Small, Medium and Large size with age $20 \pm 2$ years volunteered to participate in tests. They were provided with a participant informations sheet, informing the procedures of the experiment. The tests were conducted in a performace room at a temperature of $20 \pm 2^{\circ} \mathrm{C}$, relative humidity of $50 \pm 5 \%$. Before the tests, the garments were then hung in the enviromental chamber for $24 \mathrm{~h}$ before the test. Subjects entered the room and rested for $10 \mathrm{~min}$ to adapt to the room conditions. Each day only one subject was tested. The experiment consisted of two parts. Firstly, the body measurements of every subjects were measured by tape measure for the avatar in $3 \mathrm{D}$ virtual garment simulations (Figure 1).

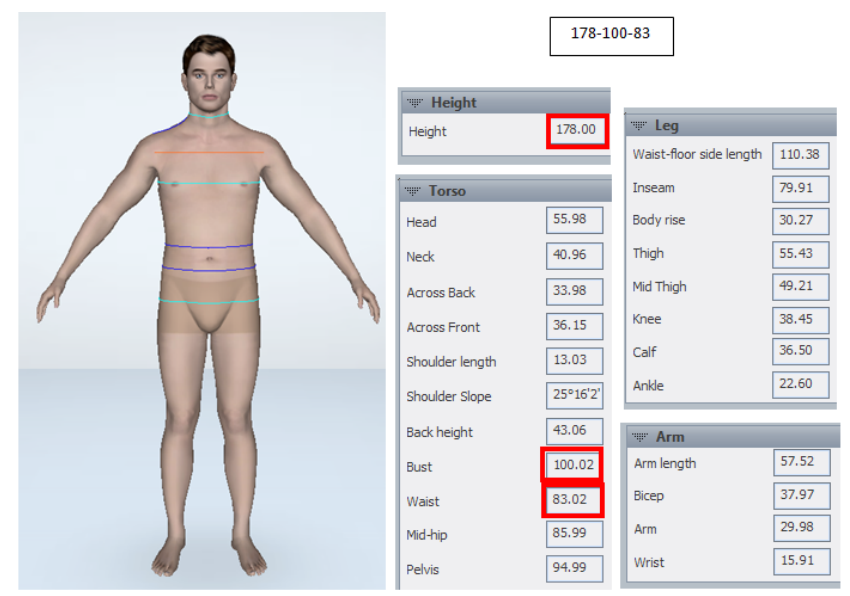

Figure 1. Measurement points on body

The fabric properties were input into the simulations and the fabric extension maps were obtained and compared. In second part, the temperature distributions of clothing outer surface was detected by another non-contact measuring tool, infrared thermal camera (Flir E40 with $0.07^{\circ} \mathrm{C}$ thermal sensitivity). Subjects were asked to stand on footprints and keep the arm straight. The locations of infrared thermal camera and body posture were kept constant during the measurements. The infrared thermal measurements included 
two steps, first subjects were asked to wear tshirts and body postures were photographed then subjects rested for ten min wearing tshirts and body postures were photographed again. The clothing surface temperatures were then analyzed by thermal imaging software (Flir Tools) to get the maximum, minimum and average temperatures on bust (B1), waist (B2) and hip (B3) sections. To investigate the regional fabric extensions on human torso, six sections (bust, waist, pelvis, back bust, back waist and hip) were simulated according to the height of the human torso. To measure the surface temperatures of clothing, six measuring areas were drawn on the frontal and rear infrared photos of upper body, corresponding to the sections of fabric extensions.

\section{III.RESULTS AND DISCUSSIONS}

\subsection{Clothing Surface Temperatures on Body Sections}

The thermal photographs of frontal and rear body sections were analyzed by Flir Tool Software (Figure 2).

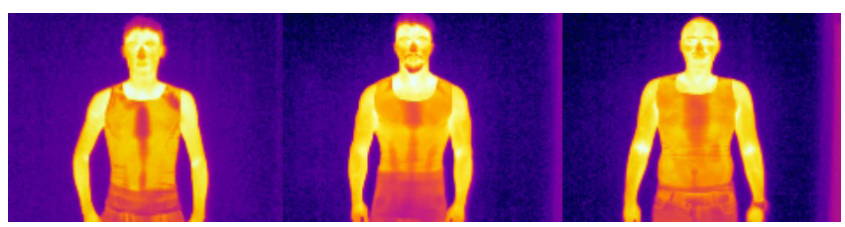

Figure 2. The thermal photographs of subjects having small, medium and large size respectively

The average clothing surface temperatures of six body sections of two tshirts (G1 and G2) are shown in Figure 3. It shows that the average temperatures when first worn (B1, $\mathrm{B} 2$ and $\mathrm{B} 3)$ and after ten minutes resting (B1A, B2A and B3A).

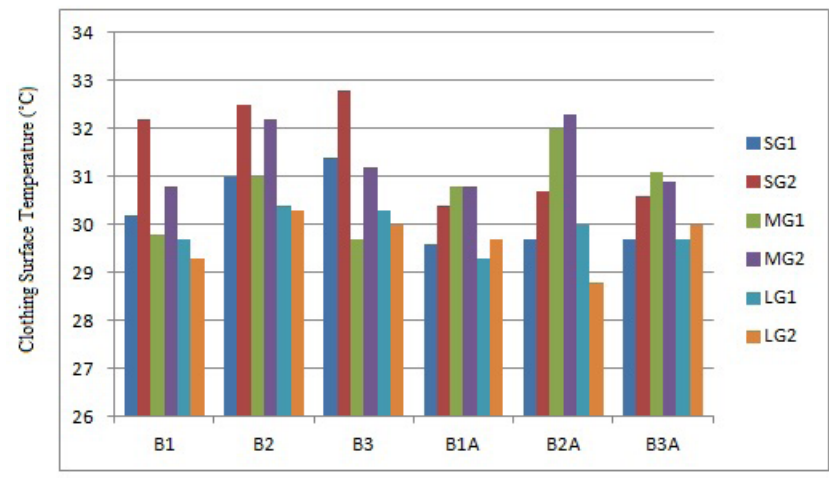

Frontal Body Sections

Figure 3. The average clothing surface temperatures on frontal body sections.
Three subjects having small, medium and large size, tried on two experimental tshirts (SG1, SG2, MG1, MG2, LG1 and LG2). The surface temperatures of on small size body (SG1 and SG2) have the lowest surface temperatures due to the highest air gap thickness. The SG1 and SG2 tshirts have not the close fitting as much as the others. After ten minutes, SG1 and SG2 shows the highest temperature decrease because the tshirts provide thermal isolation due to air gaps (Figure 4).

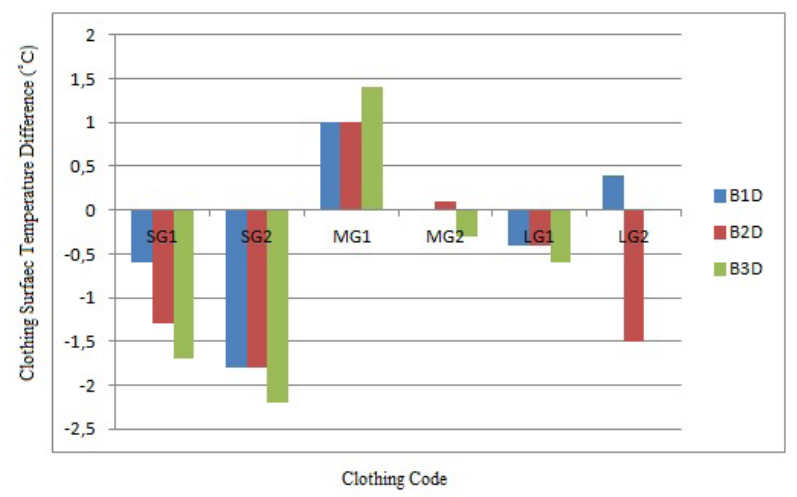

Figure 4. The clothing surface temperature differences on frontal body sections between first worn and after ten minutes

The surface temperatures of on medium size body (MG1 and MG2) show stable temperature changes. The tshirt MG1 have the highest temperature after 10 miutes resting. This case can help the body to decrease its core temperature. The tshirt MG2 shows almost the same temperature after 10 minutes resting. The tshirts LG1 and LG2 have the most closing fit form and the fabric extensions are much more the others (Figure 6). This case gives a negative effect on heat transfers and cause the body to lose its core temperature easily. The subject having large size mentioned that the tshirts were not so comfortable for himself.

All the average surface temperatures on rear body sections shows decreasing because of the air gaps occurred on concave areas and large contact surface (Figure 5). The tshirt MG1 shows lowest temperature decrease taking into account all sections. The tshirt SM1 and SM2 provide thermal isolation due to air gaps again like the frontal body sections. 


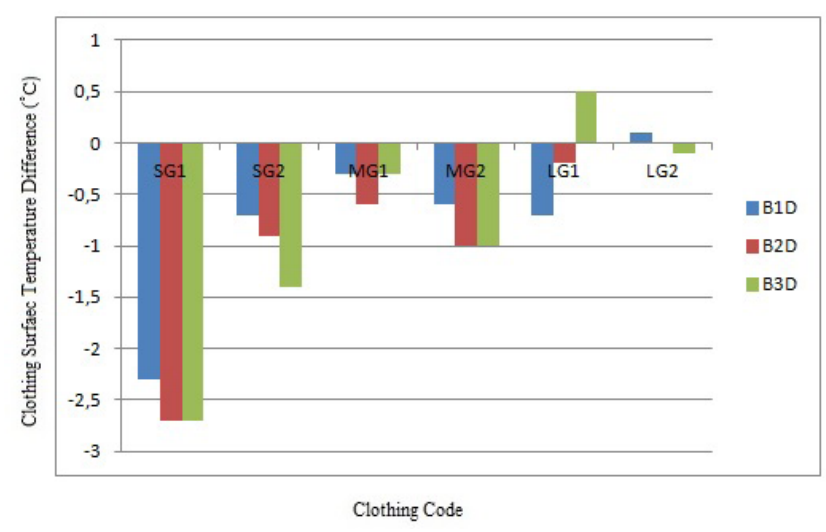

Figure 5. The clothing surface temperature differences on rear body sections between first worn and after ten minutes

\subsection{Fabric Extensions on Body Sections}

Fabric extension results were taken from virtual avatars in 3D virtual garment simulation (Modaris 3D) having the same body measurements. Figure 6 shows the results of G1 tshirt on avatars' body having (a) small size (b) medium size (c) large size.

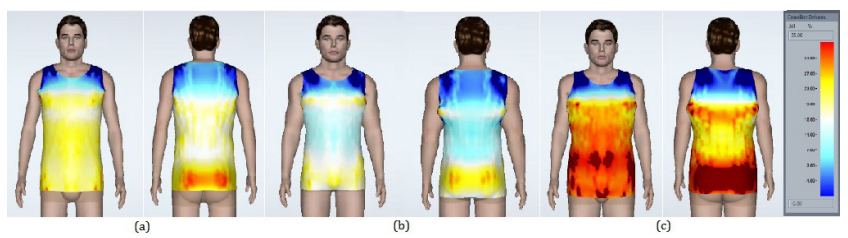

Figure 6. Fabric extensions of G1 tshirt on avatars' body having (a) small size (b) medium size (c) large size

\section{IV.CONCLUSIONS}

In this study, we investigated the effect of garment fit and fabric extension on the thermal transfer performance of clothing. Non-Contact Measuring Tools can help to compare the results easily. The experimental results show that compression garment fit and consequently fabric extension influence the heat transfer and clothing surface temperatures. In the sportswear industry, compression sports garment are worn next to skin and are direct contact with the body surface, their thermal comfort properties are effective on overall clothing comfort. Fabric extension within certain limits can help to control the body thermoregulation. The optimum fabric extension limits should be defined for better body thermal balance. So optimal garment fit should be defined for designing sportswear, especially for performance sportswear.

\section{Acknowledgements}

This study was supported by Academic Staff Training Program Coordination Unit of Suleyman Demirel University under Project Number: OYP05800-DR-13 and 20164747/ SDU.05800

\section{References}

[1] Liu, R., Little, T., \& Williams, J. R. (2014). Compression form-fitted athletic wear: Pressure performance, moisture management properties under different tension ratios, and corresponding psychophysical responses. Fibers and Polymers, 15(3), 632-644.

[2] Gupta, D., Chattopadhyay, R., \& Bera, M. (2011). Comfort properties of pressure garments in extended state.

[3] Mert, E., Böhnisch, S., Psikuta, A., Bueno, M. A., \& Rossi, R. M. (2016). Contribution of garment fit and style to thermal comfort at the lower body. International journal of biometeorology, 60(12), 1995-2004.

[4] Fournet, D., \& Havenith, G. (2017). Assessment of Sport Garments Using Infrared Thermography. In Application of Infrared Thermography in Sports Science (pp. 159-183). Springer, Cham. 